This site uses cookies. More info $\boldsymbol{\otimes}$ Close By continuing to browse the site you are agreeing to our use of cookies. Find out more here Close

\title{
thelomi
}

Research Methods \& Reporting

\section{Use of multiperspective qualitative interviews to understand patients' and carers' beliefs, experiences, and needs}

BMJ 2009; 339 doi: https://doi.org/10.1136/bmj.b4122 (Published 14 October 2009) Cite this as: BMJ 2009;339:b4122

Marilyn Kendall, research fellow, Scott A Murray, St Columba's Hospice professor of primary palliative care, Emma Carduff, research fellow, Allison Worth, senior research fellow, Fiona Harris, research fellow, Anna Lloyd, research fellow, Debbie Cavers, research fellow, Liz Grant, senior lecturer, Kirsty Boyd, honorary clinical senior lecturer, Aziz Sheikh, professor of primary care research and development

${ }^{1}$ Centre for Population Health Sciences: General Practice Section, University of Edinburgh, Edinburgh EH8 9DX

Correspondence to: M Kendall Marilyn.Kendall@ed.ac.uk

- Accepted 3 August 2009

A better understanding of the needs of patients and their carers can help improve services. Marilyn Kendall and colleagues describe how to conduct multiperspective studies

Linked interviews conducted with patients and their informal and professional carers can generate a richer understanding of needs and experiences than the single perspective most commonly used in qualitative studies. Interview dyads or triads, where two or three participants are interviewed as a set or case study, can explore complex complementary as well as contradictory perspectives, and there is considerable scope for using this method in a range of long term conditions.

Based on our experiences of conducting multiperspective studies and drawing on the wider literature, we summarise when researchers might find multiperspective interviews a useful approach, discuss how to use this approach, consider the data that are generated, and highlight potential pitfalls and how to avoid these.12345 This paper builds on our previous article discussing the need for longitudinal qualitative approaches. 6 Combining longitudinal and multidimensional interviews can prove particularly valuable.

\section{When are multiperspective interviews appropriate?}

Multiperspective interviews are potentially most useful when seeking to

- Understand relationships and dynamics among patients, their families, and professional carers

- Explore similarities and differences in the perceptions of patients and their family and professional carers 
- Understand the individual needs of patients, carers, and professionals

- Integrate suggestions for improving services from patients, carers, and professionals.

We have used the approach mainly in the context of palliative care, where family and professional carers have an important role (table $\underline{\Downarrow}) .12345$ Other researchers have shown the value of a multiperspective approach in diverse clinical areas including the pattern of symptoms in childhood cancer; the couple's experience of breast cancer recurrence and prostate cancer; the complex clinician-patient interactions around requests for physician-assisted suicide; and development of a model of care giving skills for relatives of people with cancer.7 891011

Dyad combinations typically include husband-wife, mother-child, and patient-carer. Triad combinations, as in a study exploring children's, parents', and professionals' views about tissue donation for research, have been used far less often.12 In a study of patient-family dyads about information disclosure, the researchers concluded that interview triads would have given broader and deeper information.13 More recently, another study used interviews with patients, carers, and professionals to explore views about when prognostic discussions should be instigated.14

\begin{tabular}{|c|c|c|c|}
\hline Aims of study & Patients & $\begin{array}{l}\text { Informal } \\
\text { carers }\end{array}$ & Professional carers \\
\hline $\begin{array}{l}\text { To compare the illness } \\
\text { trajectories, needs, and service } \\
\text { use of patients with cancer and } \\
\text { those with advanced non- } \\
\text { malignant disease }\end{array}$ & $\begin{array}{l}20 \text { patients } \\
\text { with } \\
\text { inoperable } \\
\text { lung cancer } \\
\text { and } 20 \text { with } \\
\text { advanced } \\
\text { heart failure }\end{array}$ & $\begin{array}{l}\text { Spouses, } \\
\text { daughters, } \\
\text { cousins, } \\
\text { warden of } \\
\text { sheltered } \\
\text { accommodation }\end{array}$ & $\begin{array}{l}\text { General practitioners, } \\
\text { district nurses, community } \\
\text { palliative care nurse, } \\
\text { cardiologist, hospital } \\
\text { chaplain }\end{array}$ \\
\hline $\begin{array}{l}\text { To inform future service } \\
\text { developments for people with } \\
\text { advanced heart failure }\end{array}$ & $\begin{array}{l}30 \text { patients } \\
\text { with } \\
\text { advanced } \\
\text { heart failure }\end{array}$ & $\begin{array}{l}\text { Spouses, } \\
\text { daughters }\end{array}$ & $\begin{array}{l}\text { General practitioners, heart } \\
\text { failure nurses, geriatricians, } \\
\text { day care staff, community } \\
\text { nurses, hospice staff, } \\
\text { voluntary workers }\end{array}$ \\
\hline $\begin{array}{l}\text { To understand the experience of } \\
\text { being diagnosed and living with } \\
\text { a brain tumour (2005-9) }\end{array}$ & $\begin{array}{l}26 \text { patients } \\
\text { with } \\
\text { suspected } \\
\text { malignant } \\
\text { glioma }\end{array}$ & $\begin{array}{l}\text { Spouses, } \\
\text { parents, } \\
\text { daughters, } \\
\text { sisters }\end{array}$ & $\begin{array}{l}\text { General practitioners, } \\
\text { clinical oncologists, } \\
\text { neurosurgeons, hospital } \\
\text { nurses, palliative care } \\
\text { nurses, district nurses, } \\
\text { allied health professionals, } \\
\text { social worker, hospital } \\
\text { chaplains }\end{array}$ \\
\hline $\begin{array}{l}\text { To identify the needs and service } \\
\text { use of patients with chronic } \\
\text { obstructive pulmonary disease, } \\
\text { and to map a framework for an } \\
\text { intervention study (2006-9) }\end{array}$ & $\begin{array}{l}20 \text { patients } \\
\text { with severe } \\
\text { disease }\end{array}$ & $\begin{array}{l}\text { Spouses, } \\
\text { daughters }\end{array}$ & $\begin{array}{l}\text { General practitioners, } \\
\text { respiratory physicians, } \\
\text { community based and } \\
\text { hospital based respiratory } \\
\text { nurses, nurse from day } \\
\text { hospice }\end{array}$ \\
\hline
\end{tabular}




\begin{tabular}{|c|c|c|c|}
\hline Aims of study & Patients & $\begin{array}{l}\text { Informal } \\
\text { carers }\end{array}$ & Professional carers \\
\hline $\begin{array}{l}\text { To understand end of life care } \\
\text { needs of South Asian patients in } \\
\text { Scotland and to understand } \\
\text { barriers and facilitators to } \\
\text { accessing services }\end{array}$ & $\begin{array}{l}25 \text { South } \\
\text { Asian } \\
\text { patients }\end{array}$ & $\begin{array}{l}\text { Spouses, } \\
\text { children }\end{array}$ & $\begin{array}{l}\text { General practitioners, } \\
\text { specialist nurses, social } \\
\text { worker, oncologist, } \\
\text { occupational therapist, } \\
\text { hospital manager }\end{array}$ \\
\hline $\begin{array}{l}\text { To describe the spiritual needs of } \\
\text { patients approaching death and } \\
\text { to explain how and by whom } \\
\text { such needs could best be met }\end{array}$ & $\begin{array}{l}20 \text { patients } \\
\text { with } \\
\text { advanced } \\
\text { malignant } \\
\text { and non- } \\
\text { malignant } \\
\text { disease }\end{array}$ & $\begin{array}{l}\text { Spouses, } \\
\text { children, sisters }\end{array}$ & $\begin{array}{l}\text { General practitioners, } \\
\text { hospice staff }\end{array}$ \\
\hline $\begin{array}{l}\text { To explore the psychosocial } \\
\text { impact of living with anaphylaxis } \\
\text { on adolescents and their } \\
\text { parents; their management of } \\
\text { the condition; and perceptions of } \\
\text { health care provision }\end{array}$ & $\begin{array}{l}7 \\
\text { adolescents } \\
\text { with } \\
\text { anaphylaxis }\end{array}$ & Parents & None \\
\hline $\begin{array}{l}\text { To explore perceptions about } \\
\text { anaphylaxis and its management } \\
\text { and to formulate interventions } \\
\text { and evaluate their acceptability } \\
\text { to adolescents, parents, and } \\
\text { professionals (2008-9) }\end{array}$ & $\begin{array}{l}26 \\
\text { adolescents } \\
\text { with } \\
\text { anaphylaxis }\end{array}$ & Parents & $\begin{array}{l}\text { Allergy specialists, general } \\
\text { practitioners, specialist } \\
\text { nurses, school nurses, } \\
\text { psychologists, resuscitation } \\
\text { officers, dietitians, food and } \\
\text { drug industry } \\
\text { representatives, voluntary } \\
\text { sector staff }\end{array}$ \\
\hline
\end{tabular}

Details of multiperspective interview studies

\section{How do you conduct multiperspective interview studies?}

\section{Recruitment}

Our experiences have highlighted the value of a stepwise approach starting with the patient, then recruiting an informal carer, and finally health or social care professionals. Before patients give their consent, they understand that they will be invited to nominate the family members and professional carers who are most important or central to their care. The aim is to recruit those informants most likely to have relevant information for the study. Consent is obtained from each individual in turn. The aim is to complete a set of interviews over a few days or weeks, ensuring that all participants have the opportunity to reflect on whether they wish to participate and are clearly informed that they are free to withdraw at any time without adversely affecting their or their family's care and support. We found that patients were happy and able to recommend a range of key informal carers and professionals for interview. When approached in this way, the majority of carers were willing to participate.

\section{Data generation}

We usually begin by interviewing the patient alone and then the family carer in order to generate separate accounts. However, in about half the cases in our palliative care studies the patient and family carer preferred to be interviewed 
together. Although this can constrain the discussions, at other times patients and carers were able to prompt each other to mention or expand on specific issues or experiences. Interviewing the carer simultaneously also has the advantage of allowing additional insights into the relationship. We typically interview professionals last and have found that telephone interviews, which can easily be recorded using a telephone adaptor, are the most efficient and acceptable method.

\section{Analysis}

Analysis proceeds concurrently with data generation, allowing emerging themes and concepts to be reflected on with subsequent participants. Interview transcripts and field notes from each set of patient, family, and professional carer can, however, be analysed as separate case studies and then as groups of case studies. Even a small sample will generate a variety of analytical opportunities, so qualitative software such as NVivo (www.qsrinternational.com) can be useful in organising these data.

If a longitudinal, serial dyad or triad approach is used, analysis may also be undertaken across all first interviews, then across all second and subsequent sets of interviews, or by synthesising data relating to specific key points or transitions, such as interviews with patients approaching the last days of life. By coding within as well as between cases, changes over time linked to particular patients and their associated carers and professionals can be retained and analysed in considerable depth. The context of individual patient journeys is preserved while undertaking the broader thematic analysis.15 Creation of a matrix linking cases to the coding frame can help writing and interpretation, maximising the strengths of multiperspective data.

\section{What type of findings might you expect?}

\section{Understanding of relationships and dynamics}

Multiperspective interviews can enhance understanding of interactions such as patient-carer-doctor relationships or provide rich insights into the multifaceted roles of patients within their families and communities and the way in which these serve to maintain their identity. In one case, we conducted interviews with the patient, his wife, a specialist nurse, the church minister, his general practitioner, and an overnight nurse to develop a complex account of the experience of dying at home from lung cancer.16

\section{Comparison of perceptions of patients, their family, and carers}

Interviews with patient, family, and professional sometimes show concordance in their perceptions. For example, we found that an elderly man with progressive and unstable heart failure described feelings of lack of control and helplessness that were confirmed by his wife, who added that she felt like she was in prison with him. The general practitioner was experiencing similar disempowerment because he felt that he could do very little for such people. 2 In our study of the end of life care needs of South Asian patients in Scotland a participant recounted how he had suffered from discrimination and generally poor care. A linked professional confirmed that this patient's dietary needs had been unmet and his treatment been discriminatory. 3

However, multiperspective data can also show differing concerns among participants. In our allergy studies, adolescents and parents gave contrasting views of the readiness of adolescents to accept responsibility for managing their condition, with parents far more anxious than adolescents about the dangers of the adolescents' ability to manage risk.5 In a study of mothers with early breast cancer and their children, although the mothers assumed the children were unconcerned by the diagnosis, the children described themselves as being overwhelmed.17 We found some health professionals diagnosing clinical depression at the end of life, when the patient considered the problems to be more existential or spiritual.4

\section{Understanding of individual needs of participants}


Interviews with multiple people can show different facets of the needs and coping strategies of participants in their role as patient, carer, or professional. Several general practitioners, as well as describing their need for better access to community nursing and social services to support dying patients at home, acknowledged that personal stresses and a lack of adequate training in communication were important barriers to effective care.1

\section{Suggestions for improving services}

Linked interviews not only show the complexity of individual situations and help researchers understand deficiencies in care from different perspectives, they may also contribute to formulating relevant and workable recommendations for improving services. We organised focus groups of key professionals, patients, and carers to discuss our multiperspective interview data and used the discussion to direct formulation of a framework for planning care for people with advanced heart failure.2 18 Interviews with bereaved carers, for example, provided in-depth accounts of their experiences that could be integrated and compared with those of the professional carers. We have also developed service recommendations by feeding back interview findings to separate groups of professional, patient, and family participants and asking them to comment on potential interventions.

\section{Potential pitfalls and how to avoid them}

\section{Recruitment issues}

Recruiting carers into a study at around the same time as the patient might seem to add complexity. Although some patients may be less willing to participate if their family carer is also to be interviewed, it can aid recruitment of vulnerable and potentially hard to access patients because the carer moves from being a protective gatekeeper to a participant.18 Inclusion of patients who may not have an obvious family carer or friend is important, and careful exploration may identify another supportive relationship_for example, a lung cancer patient identified a sheltered housing warden.1 We have occasionally had difficulty in recruiting busy professionals identified by patients as a key informant, and competing pressures, such as work or caring for a young family can hinder participation by family carers. Flexibility about the place and time of the interview makes refusal unusual.

\section{Patients and carers opting to be interviewed together}

Interviewing participants together is appropriate if this has been requested by participants. This can, however, have costs as well as benefits. Hearing the individual voices of the patient and carer adequately and managing information that may be sensitive or personal in the context of a joint interview can be challenging. As most interviews take place in the patient's home, a carer wishing to add information sometimes takes the opportunity for a word alone when showing the interviewer out or, for example, by inviting the researcher to look at the garden. Patients might suggest the carer make a cup of tea, which then allows them to share information they did not want the carer to hear.

When interviews are separate some carers use the patient interview as an opportunity to go out or carry out short social activities. In our brain tumour study we found that some participants chose separate interviews when they had specific issues to discuss or were not coping or communicating well with their carers.

Joint interviews are particularly valuable when patients have cognitive impairment or communication difficulties.19 Steinhauser has sought to overcome the difficulties of joint interviewing by providing two researchers to interview the patient and carer independently, but care must be taken not to impose separate, time consuming interviews on participants.20

\section{Ethical issues}

The ethical pitfalls of multiperspective research should be considered at all stages of the study. When interviewing a family or professional carer after the patient, it is often helpful to build on information from the patient interview. However, care must be taken to preserve confidentiality, particularly as carers may be curious or concerned about what has been said. Ethical issues around acting on the basis of research findings may be more acute when areas 
of concern-for example, about quality of care or relationships-involve or are corroborated by different interviewees. This method places emotional demands on researchers, especially if generating accounts over time, so support and debriefing from senior staff must be available.

\section{Lack of clarity about aims and analytical strategy}

Clear aims and analytical methods need to be set out and agreed at the outset because the quantity of data generated can otherwise rapidly prove overwhelming. When conducting a mixture of paired and individual interviews, both separate and joint interviews should be analysed transparently in the context in which they were generated.21

\section{Conclusions}

To develop personalised whole person care, we need to use patient centred research methods that can capture the multidimensional nature of the illness experience and place this understanding within a familial and health service context. Concerns about the time consuming nature of the data generation and the fact that fewer participants can be sampled have limited the use of this research method. Many of the potential barriers can be overcome with appropriate planning and groundwork. Generating data from different sources can make a major contribution to identifying people's needs and preferences.22 Such studies elicit users' views about care in the context of their experiences and integrate these with those of professionals to provide practical recommendations about how services might be delivered more effectively.

\section{Summary points}

Case linked interviews with patients and their carers can generate a richer understanding of needs and experiences

Such studies can provide practical recommendations about how to deliver services

Serial multiperspective interviewing is particularly valuable in understanding changes over the course of an illness

\section{Notes}

Cite this as: $B M J 2009 ; 339: b 4122$

\section{Footnotes}

- We thank the Chief Scientist's Office of the Scottish Government, the Department of Health, London, Macmillan Cancer Support, the Economic and Social Research Council, and E Wiseman for funding the studies, and Hilary Pinnock and Michael Gallagher for permitting their studies to be highlighted.

- Contributors: SAM, MK, and AS conceived the paper. All the authors wrote it and have approved the final draft. MK is the guarantor.

- Competing interests: None declared.

- Provenance and peer review: Not commissioned; externally peer reviewed.

\section{References}


1. Murray SA, Boyd K, Kendall M, Worth A, Benton TF, Clausen H. Dying of lung cancer or cardiac failure: prospective qualitative interview study of patients and their carers in the community. BMJ2002;325:929-32.

2. Murray SA, Worth A, Boyd K, Kendall M, Hockley J, Pratt R, et al. Patients', carers' and professionals' experiences of diagnosis, treatment and end-of-life care in heart failure: a prospective, qualitative interview study. London: Department of Health, British Heart Foundation, 2007.

3. Worth A, Irshad T, Bhopal R, Brown D, Lawton J, Grant E, et al. Vulnerability and access to care for South Asian Sikh and Muslim patients with life limiting illness in Scotland: prospective longitudinal qualitative study. BMJ2009;338:b183.

4. Grant E, Murray SA, Kendall M, Boyd K, Tilley S, Ryan D. Spiritual issues and needs: perspectives from patients with advanced cancer and nonmalignant disease. A qualitative study. Palliat Support Care 2004;2:371-8.

5. Akeson N, Worth A, Sheikh A. The psychosocial impact of anaphylaxis on young people and their parents. Clin Exp Allergy2007;37:1213-20.

6. Murray S, Kendall M, Carduff E, Worth A, Harris F, Lloyd A, et al. Use of serial qualitative interviews to understand patients' evolving experiences and needs. BMJ2009;339:b3702.

7. Woodgate RL, Degner LF. Cancer symptom transition periods of children and families. J Adv Nurs2004;46:358-68.

8. Lewis FM, Deal LW. Balancing our lives: a study of the married couple's experience with breast cancer recurrence. Oncol Nurs Forum 1995;22:943-53.

9. Harden JK, Northouse LL, Mood DW. Qualitative analysis of couples' experience with prostate cancer by age cohort. Cancer Nursing 2006;29:367-77.

10. Back AL, Starks H, Hsu C, Gordon JR, Bharucha A, Pearlman RA. Clinician-patient interactions about requests for physician-assisted suicide: a patient and family view. Arch Intern Med2002;162:1257-65.

11. Schumacher KL, Beidler SM, Beeber AS, Gambino P. A transactional model of cancer family caregiving skill. Adv Nurs Sci2006;29:271-86.

12. Dixon-Woods M, Cavers D, Jackson CJ, Young B, Forster J, Heney D, et al. Tissue samples as "gifts" for research: a qualitative study of families and professionals. Med Law Int2008;9:131-50.

13. Kirk P, Kirk I, Kristjanson LJ. What do patients receiving palliative care for cancer and their families want to be told? A Canadian and Australian qualitative study. BMJ2004;328:1343-6.

14. Clayton JM, Butow PN, Tattersall MH. When and how to initiate discussion about prognosis and end-of-life issues with terminally ill patients. J Pain Symptom Manage 2005;30:132-4.

15. Yin R. Case study research: design and methods. London: Sage, 2009.

16. Murray S, Kendall M, Boyd K, Worth A, Benton TF. Patient and carer perspectives: a man with inoperable lung cancer. Prog Palliat Care2003;11:321-6.

17. Forrest G, Plumb C, Ziebland S, Stein A. Breast cancer in the family-children's perceptions of their mother's cancer and its initial treatment: qualitative study. BMJ2006;332:998-1003.

18. Jaarsma T, Beattie JM, Ryder M, Rutten FH, McDonagh T, Mohacsi P, et al. Palliative care in heart failure: a position statement from the palliative care workshop of the Heart Failure Association of the European Society of Cardiology. Eur $J$ Heart Failure 2009;11:433-43.

19. Pratt R. Nobody's ever asked how I felt. In: Wilkinson H, ed. The perspectives of people with dementia: research methods and motivations. London: Jessica Kingsley, 2002.

20. Steinhauser KE, Clipp EC, Hays JC, Olsen M, Arnold R, Christakis NA, et al. Identifying, recruiting, and retaining seriouslyill patients and their caregivers in longitudinal research. Palliat Med2006;20:745-54.

21. Gysels M, Shipman C, Higginson IJ. Is the qualitative research interview an acceptable medium for research with palliative care patients and carers? BMC Med Ethics 2008;9:7.

22. Johnson M, Lehman R, Twycross R. Heart failure and palliative care: a team approach. London: Blackwell, 2006. 